\title{
Jenis-Jenis Tumbuhan Suku Zingiberaceae di Cagar Alam Pangi Binangga Sulawesi Tengah
}

\section{(Plant Species of Zingiberaceae In The Pangi Binangga Nature Reserve, Central Sulawesi)}

\author{
Ramadanil Pitopang ${ }^{1}$, Reza Rizaldi ${ }^{1}$, M. Fajri Ramadhan M Saleh ${ }^{2}$, Panji A. Ramawangsa ${ }^{3}$ \\ $\left.{ }^{1}\right)$ Jurusan Biologi, FMIPA Universitas Tadulako, Palu, 94117 \\ $\left.{ }^{2}\right)$ UPT Keanekaragaman Hayati Sulawesi Sulawesi, Universitas Tadulako Palu, 94117 \\ $\left.{ }^{3}\right)$ Jurusan Arsitektur, FT Universitas Bengkulu, Bengkulu, 38371 \\ *Email:rmaumir@gmail.com
}

(Article History: Received 14 November 2020; Revised 15 December 2020; Accepted 5 January 2021)

\begin{abstract}
ABSTRAK
Penelitian tentang keanekaragaman jenis jahe-jahean (Zingiberaceae) di Cagar Alam Pangi Binangga telah dilakukan dari bulan Oktober 2019 - Januari 2020. Penelitian bertujuan untuk mengkaji jenisjenis tumbuhan yang tergolong Zingiberaceae di Cagar Alam Pangi Binangga. Penelitian dilakukan secara survei di lapangan, menggunakan metoda eksplorasi (jelajah). Identifikasi spesimen dilakukan di Laboratorium Biosistematika Tumbuhan Jurusan Biologi Fakultas Matematika dan Ilmu Pengetahuan Alam Universitas Tadulako. Hasil penelitian menunjukan terdapat sebanyak 8 jenis yang terdiri atas 4 marga. Jenis yang ditemukan adalah Alpinia eremoclamis, A. rubricaulis, Alpinia sp1, Alpinia sp2, Etlingera tubilabrum, Etlingera sp., Sulettaria sp. dan Zingiber sp.

Kata kunci: Cagar Alam Pangi Binangga; Sulawesi Tengah; Zingiberaceae
\end{abstract}

\begin{abstract}
Research on Diversity of ginger (Zingiberaceae) in the Pangi Binangga Nature Reserve has been carried out from October 2019 - January 2020. The research was aimed to determine the species of plants belong to Zingiberaceae family in the Pangi Binangga Nature Reserve. The study was conducted by survey in the field, using exploration methods (exploring). Specimen identification was carried out at the Plant Biosystematics Laboratory, Department of Biology, Faculty of Mathematics and Natural Sciences, Tadulako University. The results showed as many as 8 species consisting of 4 genera. The species found were Alpinia eremoclamis, A. rubricaulis, Alpinia sp1, Alpinia sp2, Etlingera tubilabrum, Etlingera sp., Sulettaria sp. dan Zingiber sp.

Keywords: Pangi Binangga Nature Reserve; Central Sulawesi; Zingiberaceae
\end{abstract}

\section{PENDAHULUAN}

Zingiberaceae merupakan kelompok tumbuhan Liliopsida yang tergolong dalam ordo Zingiberales bersama dengan 7 famili lainnya yaitu Strelitziaceae, Lowiaceae, Heliconiaceae Musaceae, Cannaceae, Maranthaceae, dan Costaceae (APG IV 2016), berhabitus herba teresterial yang tersebar luas secara alami di kawasan tropis dan subtropis terdiri atas 51 marga (26 diantaranya terdapat di kawasan Malesia) dan 1400 jenis (Van Balgooy 2001; Newman et al. 2004; Kress et al. 2005). Beberapa marga tumbuhan monokotil yang termasuk dalam suku Zingiberaceae adalah: Curcuma, Zingiber, Amomum, Alpinia, Etlingera, Elettariopsis, Hedychium (Utteridge dan Bramley 2015).

Menurut Newman et al. (2004) bahwa status taksonomi suku ini menjadi perhatian banyak peneliti sejak masa Linneaus, begitu juga aspek pemanfaatannya yang sebagian besar telah digunakan sebagai rempah-rempah, bumbu, obat-obatan serta tanaman hias (Heyne 1987; Van Balgooy 2001; Sukari et al. 2008; Prabhukumar et al. 2015; Pitopang et al. 2019).

Zingiberaceae tergolong dalam kelompok tumbuhan yang jenis-jenisnya memiliki nilai ekonomi yang tinggi, terutama dari genus Zingiber, Amomum, Alpinia, dan Curcuma. Jahe (Zingiber officinale), kunyit (Curcuma domestica), lengkuas (Alpinia galanga) banyak ditanam di pekarangan rumah sebagai penghasil rempah-rempah atau bahan masakan. 
Keanekaragaman

jenis-jenis

Zingiberaceae di Sulawesi Tengah kurang banyak diketahui. Pitopang et al. (2019) melaporkan sebanyak 24 jenis dari Zingiberaceae dimanfaatkan oleh masyarakat sekitar di Taman Nasional Lore Lindu Sulawesi Tengah sebagai bahan pengobatan tradisional seperti daun Alpinia eremochlamys sebagai penambah tenaga, buah katimba (Etlingera flexuosa) sebagai bahan masak/bumbu masak, rimpang lempuyang (Zingiber zerumbet) sebagai obat rematik dan sakit perut. Kajian lain terhadap aspek fitokimia dari beberapa jenis Zingiberaceae juga sudah pernah dilaporkan (Ramadanil et al. 2019). Beberapa jenis "jahe" endemik Sulawesi seperti Etlingera flexuosa dan Alpinia eremochlamys berpotensi sebagai obat anti virus HIV (Zubair et al. 2020), bersifat antijamur (Pitopang et al., 2020), juga sebagai antibakteri (Pitopang et al. 2020).

Cagar Alam (CA) Pangi Binangga adalah salah satu Cagar Alam yang terletak di Provinsi Sulawesi Tengah yang belum banyak diungkapkan keanekaragaman tumbuhannya. Kawasan ini terletak di Kabupaten Parigi Moutong memiliki luas 6.158,75 Ha, ditetapkan berdasarkan Surat Keputusan Menteri Kehutanan No. 3895/Menhut-VII/KUH/2014 tanggal 13 Mei 2014 sebagai kawasan suaka alam yang keadaan alamnya mempunyai kekhasan tumbuhan, satwa, dan ekosistemnya atau ekosistem tertentu yang perlu dilindungi dan perkembangannya berlangsung secara alami (BKSDA Sulteng, 2015).

Keanekaragaman jenis Zingiberaceae liar yang terdapat dalam kawasan konservasi Cagar Alam Pangi-Binangga belum banyak diungkapkan. Saleh dan Hartana (2018) melaporkan 5 jenis yaitu Alpinia galanga, Alpinia sp., Amomum sp., Zingiber officinale dan Zingiber zerumbet, namun jenis yang dilaporkan merupakan tanaman yang dibudidayakan oleh masyarakat sekitar kawasan. Oleh sebab itu, penelitian ini dilakukan untuk menyediakan informasi terkini mengenai Zingiberaceae khususnya di kawasan CA
Pangi Binangga. Penelitian ini bertujuan untuk menganalisis keanekaragaman jenis jahe-jahean (Zingiberaceae) di Cagar Alam Pangi Binangga yang diharapkan bermanfaat sebagai data ilmiah tentang keanekaragaman jenis "jahe-jahean" (Zingiberaceae) di Cagar Alam Pangi Binangga.

\section{METODE}

\section{Waktu dan Tempat Penelitian}

Penelitian ini dilaksanakan dari bulan Oktober 2019 - Januari 2020, bertempat di Cagar Alam (CA) Pangi Binagga Kecamatan Parigi Tengah, Kabupaten Parigi Moutong, Sulawesi Tengah (Gambar 1). Kawasan ini berjarak sekitar $68 \mathrm{~km}$ dari ibu kota Propinsi Sulawesi Tengah (Palu) yang melewati jalur trans Sulawesi dimana jalur trans tersebut ada yang termasuk daerah khusus CA Pangi Binangga. Kawasan Cagar Alam ini secara geografis terletak pada $120,026^{\circ}-120,106^{\circ}$ BT dan $0,714^{\circ}-0,816^{\circ}$ LS. Tipe ekosistem yang terdapat di kawasan ini adalah ekosistem hutan hujan tropis dataran rendah (100-1.000 m dpl), beiklim tipe A dengan rata-rata curah hujan $2.355 \mathrm{~mm} /$ tahun, suhu rata-rata $19-26{ }^{\circ} \mathrm{C}$ dan kelembaban udara $80 \%$ (BKSDA Sulteng, 2015). Identifikasi spesimen dilakukan di Laboratorium Biosistematika Tumbuhan Jurusan Biologi Fakultas Matematika dan Ilmu Pengetahuan Alam Universitas Tadulako.

\section{Prosedur Kerja}

Penelitian ini dilakukan dengan mengumpulkan seluruh jenis-jenis tumbuhan Zingiberaceae menggunakan metode jelajah (Ramadanil et al. 2019). Seluruh contoh jenis Zingiberaceae dilokasi penelitian diambil (koleksi) untuk digunakan sebagai spesimen herbarium dimana prosedur pembuatannya mengikuti Bridson dan Forman (1999). Pembuatan koleksi herbarium dengan cara mengambil bagian tumbuhan minimal $3-5$ duplikat secara lengkap, meliputi bagian daun, bunga, buah, batang dan rimpang. Selanjutnya sampel diberi label gantung berisikan informasi nomor koleksi. Setelah itu sampel dibungkus dengan kertas koran dan dimasukkan kedalam plastik kemudian disemprotkan dengan spiritus. Informasi-informasi penting yang mendukung dalam proses identifikasi dicatat pada buku lapangan, seperti tinggi, diameter tumbuhan, nama lokasi, ketinggian, habitat, nama ilmiah, nama lokal, kegunaan serta karakter-karakter 
yang mudah hilang maupun berubah ketika proses herbarium seperti warna. Bunga dan buah dari jenis yang ditemukan dikoleksi secara khusus dengan cara menyimpannya dalam botol yang berisi larutan "Copenhagen Solution" (Bridson dan Forman 1999).

\section{PETA PENELITIAN}

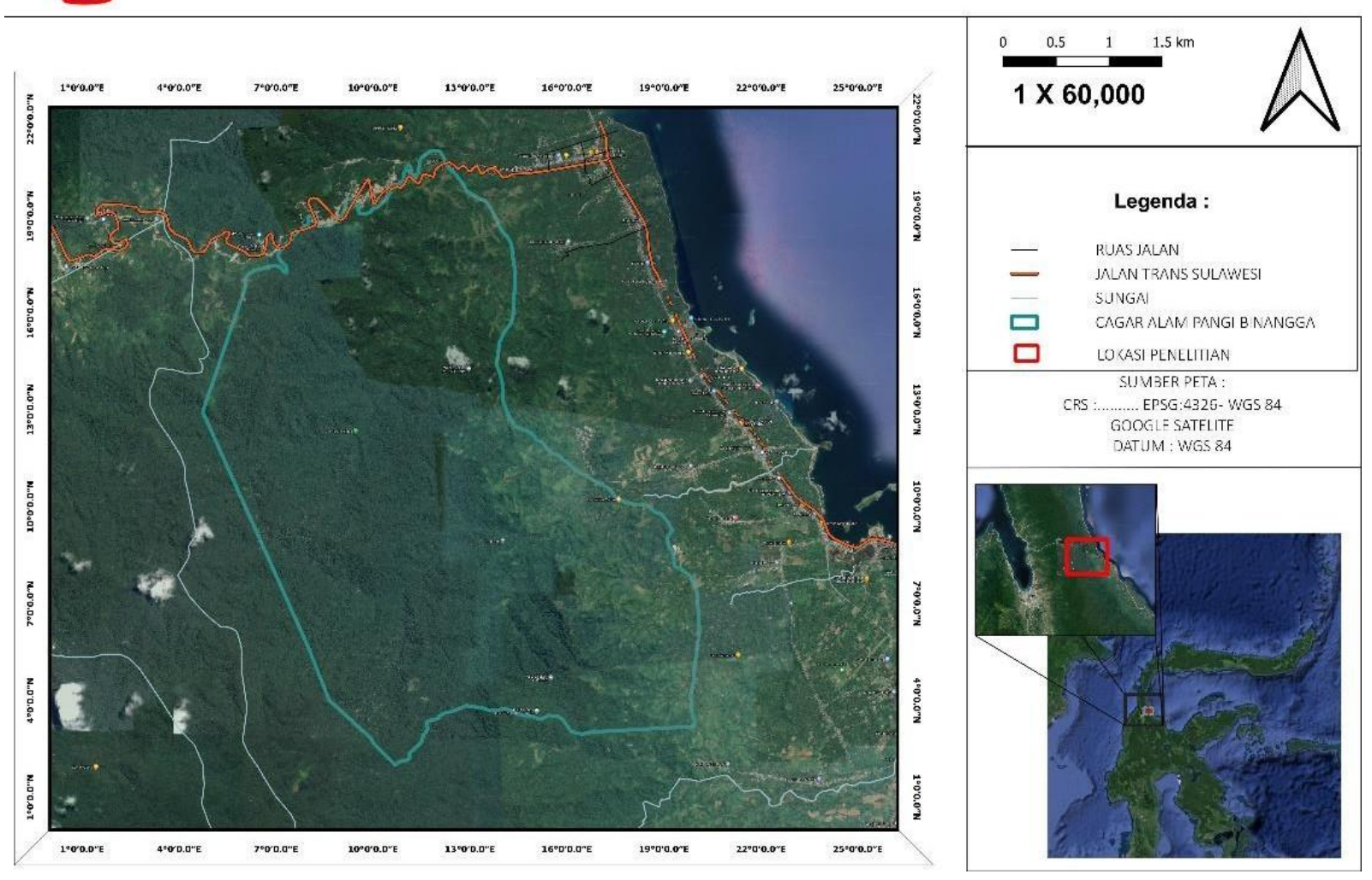

Gambar 1. Cagar Alam Pangi Binangga, Kabupaten Parigi Moutong Sulawesi Tengah.

\section{Identifikasi}

Spesimen yang berasal dari lapangan selanjutnya dibawa ke Laboratorium Biosistematik Tumbuhan, Jurusan Biologi FMIPA Univ. Tadulako untuk dilakukan pengeringan. Proses pengeringan menggunakan oven listrik. Setelah semua spesimen kering, dilanjutkan dengan dengan proses pengeplakan ("mounting") di atas kertas bebas asam, setelah itu diberi label herbarium pada sudut kanan bawah yang terisi informasi penting seperti nama famili, nama jenis, nama kolektor, tanggal, tempat dilakukan koleksi, habitat, informasi etnobotani, dan deskripsi ringkas tentang tumbuhan tersebut. Identifikasi dilakukan dengan mengacu pada: Jiang et al. (2000), Larsen et al. (1999), Utteridge and Bramley (2015), van Balgooy (1997, 1998, 2001), Poulsen (2013) serta berdasarkan referensi yang tersimpan di Herbarium Celebense (CEB) Universitas Tadulako. Selanjutnya nama ilmiah tumbuhan diverifikasi kebenarannya melalui www.plantlist.org dan www. ipni.org.

\section{Analisis Data}

Morfologi dari jenis Zingiberaceae yang didapatkan di lokasi penelitian dideskripsi berdasarkan hasil pengamatan di lapangan dan di Laboratorium. Terminologi yang digunakan dalam deskripsi mengikuti Mabberley (2008) dan Stearn (1988).

Data lapangan yang dicatat meliputi lokasi, kondisi habitat. Morrfologi tumbuha yang diamati diantaranya batang (permukaan, warna), daun (bentuk, dasar, ujung, pertulangan, panjang daun, panjang tangkai daun, permukaan daun); perbungaan (bentuk, permukaan, percabangan, jumlah bunga), bunga (warna, permukaan kelopak bunga, bentuk kelopak bunga, bentuk perhiasan bunga, panjang tangkai bunga, 
bentuk dan jumlah benang sari; buah (bentuk dan ukuran); rimpang (warna dan ukuran).

\section{HASIL DAN PEMBAHASAN}

\section{Berdasarkan}

keanekaragaman penelitian

jahe-jahean
(Zingiberaceae) di kawasan Cagar Alam Pangi Binangga, didapatkan sebanyak 8 jenis dari 4 marga yaitu: Alpinia rubricaulis, Alpinia eremochlamys, Alpinia sp1, Alpinia sp2, Etlingera tubilabrum, Etlingera megalocheilos, Sulletaria sp, Zingiber sp. Adapun jenis yang didapatkan dapat dilihat pada (Tabel 1).

Tabel 1. Jenis-jenis Zingiberaceae yang didapatkan di Cagar Alam Pangi-Binangga, Sulawesi Tengah

\begin{tabular}{|c|c|c|c|c|}
\hline No & No.Koleksi & Nama Species & Posisi geografi & $\begin{array}{l}\text { Altitute } \\
(\mathrm{m} \mathrm{dpl})\end{array}$ \\
\hline 1 & RR 001 & Alpinia rubricaulis K.Schum & $00^{\circ} 46^{\prime} 41.8^{\prime \prime} \mathrm{S} 120^{\circ} 04^{\prime} 51.4^{\prime \prime} \mathrm{E}$ & 253 \\
\hline \multirow[t]{2}{*}{2} & RR 002 & & $0^{\circ} 47^{\prime} 5.7^{\prime \prime} \mathrm{S} 120^{\circ} 4{ }^{\prime} 44.9^{\prime \prime} \mathrm{E}$ & 287 \\
\hline & & & $0^{\circ} 47^{\prime} 6.7^{\prime \prime} \mathrm{S} 120^{\circ} 4^{\prime} 43.9^{\prime \prime} \mathrm{E}$ & 306 \\
\hline \multirow[t]{2}{*}{3} & RR 003 & Alpinia eremochlamys K.Schum. & $0^{\circ} 47^{\prime} 06.5^{\prime \prime} \mathrm{S} 120^{\circ} 44^{\prime} 44^{\prime \prime} \mathrm{E}$ & 302 \\
\hline & & & $0^{\circ} 47^{\prime} 8.8^{\prime \prime} \mathrm{S} 120^{\circ} 4{ }^{\prime} 37.4^{\prime \prime} \mathrm{E}$ & 320 \\
\hline 4 & RR 004 & Alpinia sp 1 & $0^{\circ} 47^{\prime} 08.6^{\prime \prime} \mathrm{S} 120^{\circ} 4^{\prime} 38.6^{\prime \prime} \mathrm{E}$ & 322 \\
\hline 5 & RR 005 & Alpinia sp 2 & $0^{\circ} 47^{\prime} 08.6^{\prime \prime} \mathrm{S} 120^{\circ} 4^{\prime} 38.6^{\prime \prime} \mathrm{E}$ & 322 \\
\hline 6 & RR 011 & Etlingera tubilabrum A.D Poulsen. & 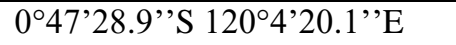 & 389 \\
\hline 7 & RR 017 & Etlingera megalocheilos (Griff) AD. Poulsen & $0^{\circ} 47^{\prime} 11.2^{\prime \prime} \mathrm{S} 120^{\circ} 4^{\prime} 44.2^{\prime \prime} \mathrm{E}$ & 319 \\
\hline 8 & RR 020 & Sulettaria $s p$ & $0^{\circ} 47^{\prime} 12.1{ }^{\prime \prime} \mathrm{S} 120^{\circ} 4^{\prime} 43.9^{\prime \prime} \mathrm{E}$ & 336 \\
\hline 9 & RR 023 & Zingiber $s p$ & $0^{\circ} 47^{\prime} 14.2^{\prime \prime} \mathrm{S} 120^{\circ} 4^{\prime} 43.5^{\prime \prime} \mathrm{E}$ & 329 \\
\hline
\end{tabular}

Deskripsi jenis-jenis Zingiberaceae yang didapatkan di Cagar Alam Pangi Binangga adalah sebagai berikut:

\section{Alpinia rubricaulis K.Schum.}

Deskripsi (Gambar 2): Herba, berkelompok, tinggi hingga $186 \mathrm{~cm}$. Rimpang 7 - 11,5 cm diameter, warna merah dan putih, panjang $9 \mathrm{~cm}$. Leafy shoots: tinggi hingga $3 \mathrm{~m}$, terdiri atas 12 - 15 daun. Ligula $0,3 \mathrm{~mm}$ panjang, berwarna hijau tua yang mempunyai ujung berbentuk meruncing. Daun berbentuk lanset, panjang $57-62 \mathrm{~cm}$ dan lebar $8-10,5$ $\mathrm{cm}$, permukaan atas mengkilat terdapat zat lilin, berwarna hijau muda, bagian bawah daun berwarna hijau pucat, pinggiran daun rata, pangkal daun bergelombang, ujung daun meruncing.

Perbungaan: Bunga majemuk, terletak pada bagian ujung, panjang tangkai perbungaan 30-60 cm, dengan 10 bunga, bunga berwarna merah muda, kelopak berwarna putih, tangkai putik berwarna merah muda panjang. Perbuahan berjumlah banyak dalam satu kumpulan bertangkai, buah oval tidak berekor, jumlah buah 46 atau lebih, warna buah merah sampai merah tua, warna tangkai buah merah dengan panjang $30 \mathrm{~cm}$, permukaan kulit buah mengkilap, berbulu halus dengan ciri utama tangkai buah berwarna merah.
Habitat dan ekologi. Tepi sungai pada tanah yang sedikit berpasir berdekatan dengan berbatuan.
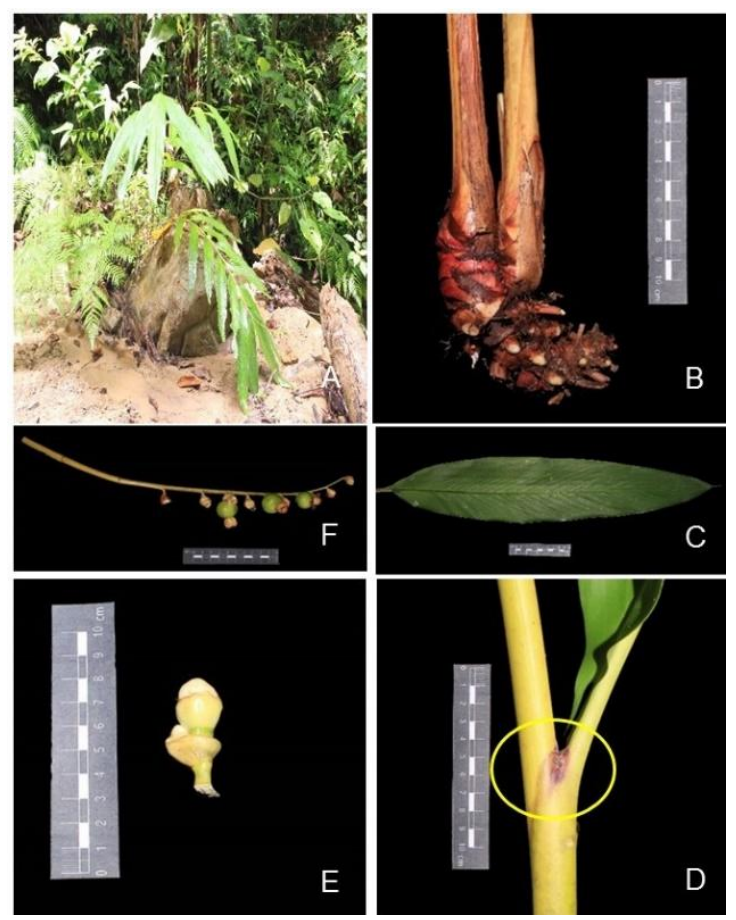

Gambar 2. A. Perawakan Alpinia rubricaulis, B. Rimpang, C. Daun, D. Ligula, E. Bunga, dan F. Buah

Spesimen. Indonesia, Sulawesi Tengah. Kabupaten Parigi Moutong. Kecamatan Parigi Tengah. Desa Binangga. Cagar Alam Pangi 
Binangga. $\quad 00^{\circ} 46^{\prime} 41.8^{\prime \prime} \mathrm{S}, \quad 120^{\circ} 04^{\prime} 51.4{ }^{\prime} \mathrm{E}$, RR001, 253 mdpl. 0 47'5.7''S, 120 4'44.9''E, RR012, 287 m. 047'6.7' 'S, 1204'43.9''E, RR014, 306 m. R. Rizaldi, Zainudin, A. Muratno, Fedrik, dan Irwandi (12 Oktober 2019). Spesimen disimpan di Laboratorium Biosistematika Tumbuhan. Jurusan Biologi FMIPA Univ. Tadulako.

\section{Alpinia eremochlamys K.Schum.}

Deskripsi (Gambar 3): Herba, tinggi $5 \mathrm{~m}$, berkelompok. Rimpang; keras dan kaku, berdiameter $10-21 \mathrm{~cm}$, berwarna merah ke unguan, panjang $9 \mathrm{~cm}$, akar tunjang tidak ada. Leafy shoot tingginya 3-5 m, dengan 2-14 daun pertangkai, berwarna merah pekat. Pelepah daun; warna oranye, dengan sedikit bulu-bulu halus.tepi rata, warna hitam, ligula $8-10 \mathrm{~mm}$ panjang, kehitaman. Lembaran daun; berbentuk oblong, panjang 56-113 cm dan lebar 6,5-15 cm, ibu tulang daun warna kuning pucat, permukaan terdapat zat lilin, mengkilat, bagian atas daun berwarna hijau muda, bagian bawah daun berwarna coklat pucat terdapat bulu, tepi daun rata, ujung terbelah, dasar membulat.

Perbungaan $51-70 \mathrm{~cm}$ panjangnya, muncul di ujung, bercabang 3, panjang tangkai $50 \mathrm{~cm}$, warna hitam dengan sedkiti oranye, dengan 140 bunga dan 30 buah. Bunga panjang $4 \mathrm{x}$ lebar $2 \mathrm{~cm}$, kelopak berbentuk mangkok, panjang $2 \mathrm{~cm}$, warna krem-kekuningan, ujung kuning pucat, tabung corolla panjangnya $1,4 \mathrm{~cm}$, dengan bulu bulu halus, tepi corolla berbentuk kurva, membulat, warna krem, labellum bentuk elip. Stamen panjangnya $2,3 \mathrm{~cm}$, filamen panjangnya $1,2 \mathrm{~cm}$, anthera $10 \times 5 \mathrm{~mm}$, kepala putik lebarnya $0,5 \mathrm{~cm}$, warna kuning. Perbuahan tangkai panjangnya $8-12 \mathrm{~cm}$, bracteola dan kelopak bunga persisten, Buah; ukuran 2 x 1,6 cm, bulat, warna hijau terang, biji banyak, warna putih pucat.

Habitat dan ekologi Kaki bukit, dan pinggir tebing di tanah yang subur/humus, sedikit berjarak dengan sungai berasosiasi dengan tumbuhan liar

Spesimen: Indonesia. Sulawesi Tengah. Kabupaten Parigi moutong. Kecamatan Parigi Tengah. Desa Binangga. Cagar Alam Pangi Binangga. $0^{\circ} 47^{\prime} 06.5^{\prime}$ 'S, $120^{\circ} 4$ '44''E, RR003, 302 mdpl. $0^{\circ} 47^{\prime} 8.8^{\prime \prime} \mathrm{S}, 120^{\circ} 4{ }^{\prime} 37.4$ ''E, RR006 320 m. R. Rizaldi, M. Fajri Ramadhan, Zainudin, A. Muratno, Fedrik, dan Irwandi (12 Oktober 2019). Spesimen disimpan di
Laboratorium Biosistematika Tumbuhan. Jurusan Biologi FMIPA Univ. Tadulako.

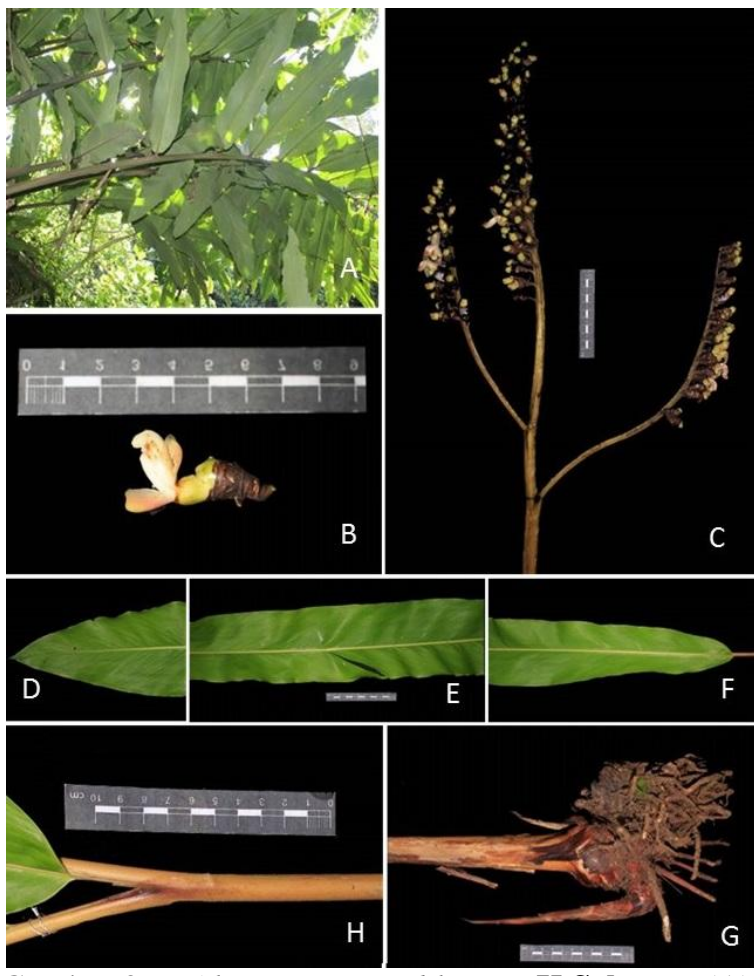

Gambar 3. Alpinia eremochlamys K.Schum. (A) Perawakan (B) Bunga (C) Perbungaan (D) Daun/ ujung daun (E) bagian tengah daun $(\mathrm{F})$ bagian bawah daun $(\mathrm{H})$ Bentuk legula $(\mathrm{G})$ Rimpang.

\section{Alpinia sp 1}

Deskripsi (Gambar 4): Herba, berkelompok, tinggi 2,7 m, Rimpang kaku dan keras, berdiameter $5-9,5 \mathrm{~cm}$, berwarna putih kekuningan. Leafy Shoot tingginya 1,5 m, terdiri atas 6 - 11 daun, Pelepah daun; hijau pucat, dengan sedikit bulu-bulu halus.tepi rata, warna hijau pucat, ligula $9 \mathrm{~mm}$ panjang warna hijau pucat. Daun berbentuk lanset, berwarna hijau muda, panjang 65,5 - $72 \mathrm{~cm}$ dan lebar $11-14$ $\mathrm{cm}$, permukaan terdapat zat lilin, bagian atas daun berwarna hijau muda, mengkilat, bagian bawah daun berwarna hijau pucat, pinggiran daun rata, pangkal daun tepi daun rata, ujung meruncing.

Habitat dan ekologi pinggir sungai pada tanah yang lembab.

Spesimen : Indonesia. Sulawesi Tengah. Kabupaten Parigi moutong. Kecamatan Parigi Tengah. Desa Binangga. Cagar Alam Pangi Binangga. 0 0 47'08.6'S, 120 4'44' E, RR004, 322 mdpl. R. Rizaldi, M. Fajri Ramadhan, 
Zainudin, A. Muratno, Fedrik, dan Irwandi (12 Oktober 2019). Spesimen disimpan di Laboratorium Biosistematika Tumbuhan. Jurusan Biologi FMIPA Univ. Tadulako.
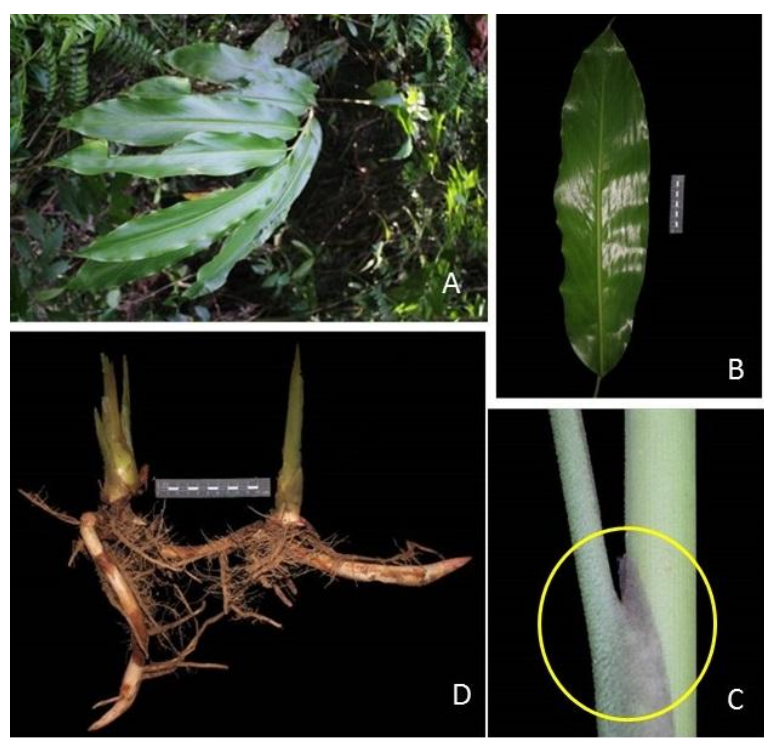

Gambar 4. Perawakan Alpinia sp1, B. Daun, C. Ligula, D. Rimpang.

\section{Alpinia sp 2}

Deskripsi (Gambar 5): Herba, berkelompok, tinggi 1,4 m. Rimpang; kaku dan keras, berdiameter 4,5 $-6,5 \mathrm{~cm}$, berwarna kuning muda sedikit oranye, panjang $16,5 \mathrm{~cm}$. Leafy shoot; tingginya hingga $140 \mathrm{~cm}$, jumlah daun 5-9 lembar. Pelepah daun; warna hijau muda. Ligula panjang $2-3,5 \mathrm{~cm}$, berwarna hijau tua. Lamina bentuk lanset berwarna hijau tua, panjang $31-44,5 \mathrm{~cm}$ dan lebar $8,5-10 \mathrm{~cm}$, permukaan terdapat zat lilin, bagian atas daun berwarna hijau tua, mengkilat, bagian bawah daun berwarna hijau pucat terdapat bulu halus seperti beludru, pinggiran daun rata sedikit bergelombang, pangkal daun sedikti menggulung.

Habitat dan ekologi pinggir sungai pada tanah yang sedikit berpasir.

Spesimen: Indonesia. Sulawesi Tengah. Kabupaten Parigi moutong. Kecamatan Parigi Tengah. Desa Binangga. Cagar Alam Pangi Binangga. 047'08.6'S, 120 4'38.6' 'E, RR005, 322 mdpl. R. Rizaldi, M. Fajri Ramadhan, Zainudin, A. Muratno, Fedrik, dan Irwandi (12 Oktober 2019). Spesimen disimpan di Laboratorium Biosistematika Tumbuhan. Jurusan Biologi FMIPA Univ. Tadulako.

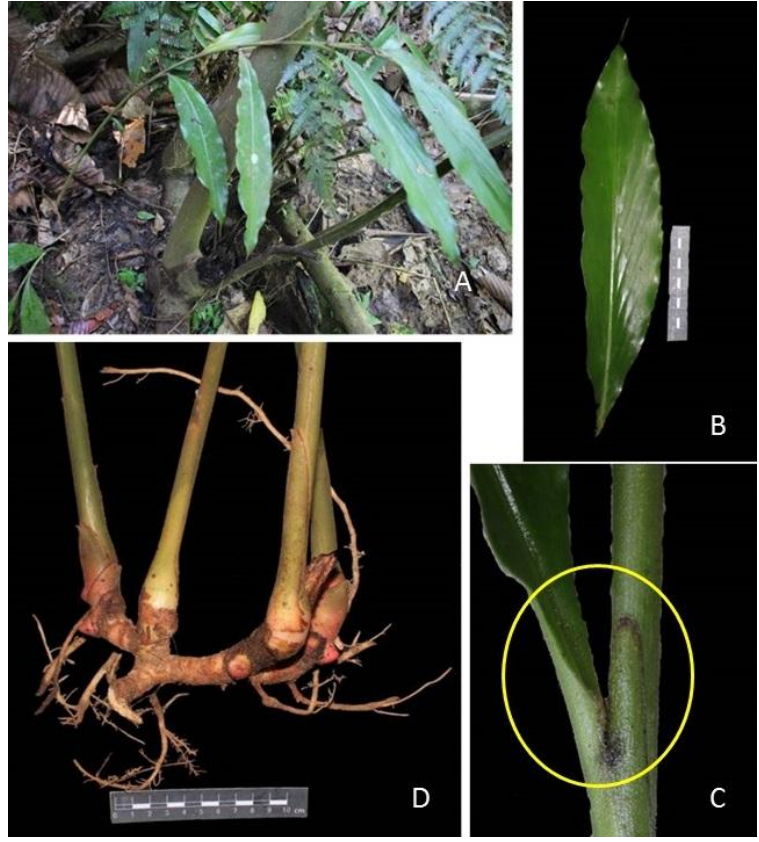

Gambar 5. Alpinia sp 2 . A. Perawakan, B. Daun, C. Ligula, D. Rimpang.

\section{Etlingera tubilabrum A.D. Poulsen}

Deskripsi (Gambar 6): Herba, berkelompok, tinggi $3-5,5 \mathrm{~m}$. Rimpang pubescen, berscale dgn jarak 4-7 cm, berwarna merah kekuningan, akar tunjang absen. Leafy shoot; panjangnya hingga $5,2 \mathrm{~m}$, bagian bawah berdiameter 7,5 cm, warna hijau kemerahan atau coklat kemerahan, dengan 10-17 daun Pelepah daun; hijau kekuningan, Ligula hingga $4 \mathrm{~mm}$ panjangnya, tersembunyi oleh dasar daun, berwarna hijau kekuningan pucat; Lembaran daun sesil, panjang 120 - 95 dan lebar 4,5 - 5,5 $\mathrm{cm}$, permukaan terdapat zat lilin, bagian atas daun berwarna hijau gelap, mengkilat, bagian bawah daun berwarna hijau pucat, pinggir daun sedikit bergelombang, pangkal daun berbentuk seperti telinga, ujung daun meruncing.

Perbungaan panjangnya $22-37 \mathrm{~cm}$, dengan 62-140 bunga, dasar bunga $3-12 \mathrm{~cm}$, tangkai bunga $17-25 \mathrm{~cm}$ panjangnya. Bunga panjangnya 4-5 cm, pedicel absen, kelopak bunga panjangnya $2-2,7 \mathrm{~cm}$, perhiasan bunga warna krem. Perbuahan tangkai panjangnya $20 \mathrm{~cm}$, kepala ukuran $23 \mathrm{X} \mathrm{cm}$, bentuk oval, dengan 110 buah per tangkai, braktea persisten, buah berukuran 3,5 panjang $\times 2,5 \mathrm{~cm}$ lebar, warna coklat pucat, berbiji ukuran $3 \times 4 \mathrm{~mm}$, aril warna merah.

Habitat dan ekologi; pinggir sungai di tanah yang penuh humus, hutan dataran rendah di bawah kanopi tertutup dan bebatuan. 
Spesimen: Indonesia. Sulawesi Tengah. Kabupaten Parigi moutong. Kecamatan Parigi Tengah. Desa Binangga. Cagar Alam Pangi Binangga. 047'28.9'S, 120 4'20.1''E, RR011, 389 mdpl. R. Rizaldi, M. Fajri Ramadhan, Zainudin, A. Muratno, Fedrik, dan Irwandi (12 Oktober 2019). Spesimen disimpan di Laboratorium Biosistematika Tumbuhan. Jurusan Biologi FMIPA Univ. Tadulako.

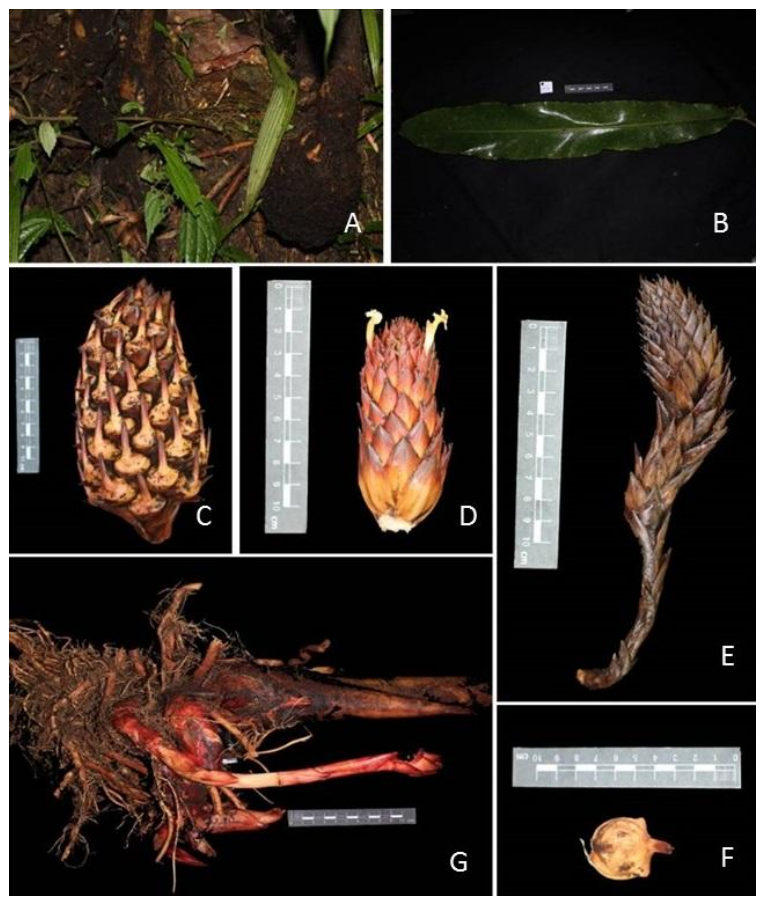

Gambar 6. Etlingera tubilabrum AD Poulsen. A Perawakan, B. Daun, C. Buah, D. Perbungaan dengan bunga (warna putih) E Tunas muda perbungaan, F. Buah, G. Rimpang.

\section{Etlingera cf. megalocheilos (Griff) AD. Poulsen}

Deskripsi (Gambar 7): Herba, berkelompok, Tinggi hingga. Rimpang panjang $1,5-25 \mathrm{~cm}$. creeping, sedikit terbenam di tanah, berdiameter $>2 \mathrm{~cm}$ diameter, berwarna kremcoklat pucat, berbuku dengan jarak $6 \mathrm{~cm}$. Leafy Shoot; hingga $5 \mathrm{~m}$ panjangnya, dengan jumlah daun hingga 26 daun, ligula panjangnya $15 \mathrm{~mm}$, warna hijau kecoklatan. Tangkai daun 15-35 $\mathrm{mm}$, kaku. Lembaran daun ukuran $78 \times 16 \mathrm{~cm}$, berbentuk pblong, melebar di ditengah, tulang tengah warna hijau pekat, warna kepucatan bagian bawah. Daun muda kaku, dasar daun sisi, ujung runcing.

Habitat dan ekologi: pinggir sungai pada tanah yang sedikit lembab.
Spesimen: Indonesia. Sulawesi Tengah. Kabupaten Parigi moutong. Kecamatan Parigi Tengah. Desa Binangga. Cagar Alam Pangi Binangga. $0^{\circ} 47^{\prime} 11.2$ ' S, 120 4'44.2' 'E, RR017, 319 mdpl. R. Rizaldi, D. Moh. Fauzan, Zainudin, A. Muratno, Fedrik, dan Irwandi (13 Oktober 2019). Spesimen disimpan di Laboratorium Biosistematika Tumbuhan. Jurusan Biologi FMIPA Univ. Tadulako.

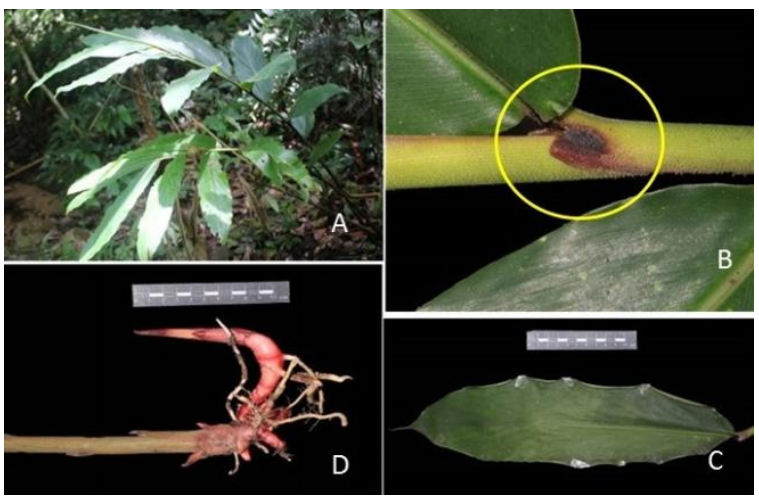

Gambar 7. Etlingera cf. megalocheilos (Griff) AD. Poulsen. A. Perawakan, B. Ligula, C. Daun. D. Rimpang.

\section{Sulettaria sp.}

Deskripsi (Gambar 8): Herba, berkelompok, tinggi $172 \mathrm{~cm}$. Rimpang cc 9,4$11 \mathrm{~cm}$ diameter, berwarna merah putih, panjang $9,5 \mathrm{~cm}$. Leafy Shoot: Tingginya hingga $180 \mathrm{~cm}$, dengan $9-18$ daun. Ligula panjang $0,5-1 \mathrm{~cm}$, berwarna hijau kemerahan, ujung bilobed. Daun berbentuk lancet, panjang $29-58 \mathrm{~cm}$ dan lebar $4-14 \mathrm{~cm}$, permukaan terdapat zat lilin, bagian atas daun berwarna hijau tua, mengkilat, bagian bawah daun berwarna hijau pucat, pinggiran daun rata, pangkal daun obtuse, ujung daun acuminate. Perbungaaan bunga majemuk, muncul di permukaan tanah, panjang $37 \mathrm{~cm}$, dengan $5-24$ bunga, $1-4$ bunga terbuka sekaligus, panjang tangkai $0,2-5 \mathrm{~cm}$, panjang bunga $1,5-2,2 \mathrm{~cm}$, berwarna merah, kelopak lebih pendek dari mahkota, panjang tubular 2 $\mathrm{cm}$.

Habitat dan ekologi; Pinggir sungai pada tanah yang sedikit lembab.

Spesimen: Indonesia. Sulawesi Tengah. Kabupaten Parigi Moutong. Kecamatan Parigi Tengah. Desa Binangga. Cagar Alam Pangi Binangga. 0 47'12.1''S, 120 4'43.9' 'E, RR020, 336 mdpl. R. Rizaldi, D. Moh. Fauzan, Zainudin, A. Muratno, Fedrik, dan Irwandi (13 Oktober 
2019). Spesimen disimpan di Laboratorium Biosistematika Tumbuhan. Jurusan Biologi FMIPA Univ. Tadulako. Merupakan genus jahe baru yang terlepas dari Elettaria sp. (Poulsen et al. 2018).
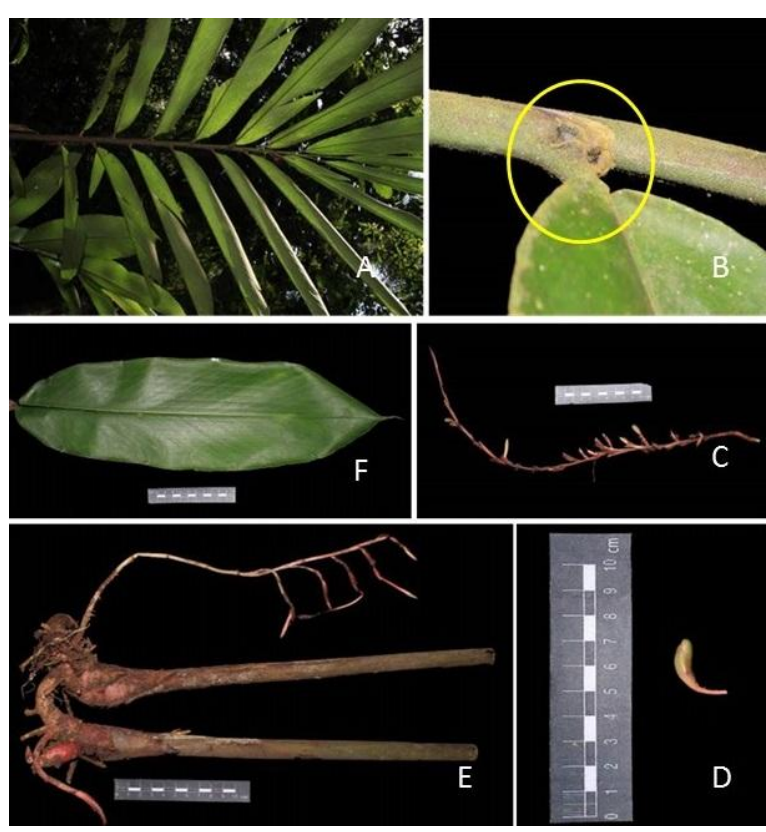

Gambar 8 Sulettaria sp .A Perawakan, B. Ligula, C. Perbungaan, D. Bunga, E. Rimpang, F. Bunga.

\section{Zingiber sp}

Deskripsi (Gambar 9): Herba, berkelompok, Tinggi 1,42 - 3,60 m. Rimpang; berdiameter $5,5-7,5 \mathrm{~cm}$, berwarna merah keputihan, panjang $12 \mathrm{~cm}$, memiliki ujung yang menjalar.Leafy shoot ; Tingginya $2 \mathrm{~m}$, dengan 7 - 13 daun. Ligula panjang $0,5-0,8 \mathrm{~mm}$, berwarna hijau kuning, ujung bilobed. Daun berbentuk lanceolate, panjang $4-35 \mathrm{~cm}$ dan lebar $1,5-12,5 \mathrm{~cm}$, permukaan terdapat zat lilin, bagian atas daun berwarna hijau kekuningan, mengkilat, bagian bawah daun berwarna hijau pucat terdapat bulu, pinggiran daun rata, pangkal daun attenuate, ujung daun meruncing.

Habitat dan ekologi: pinggir sungai di tanah yang sedikit lembab dan berdekatan dengan tanaman jenis Sulettaria sp.

Spesimen: Indonesia. Sulawesi Tengah. Kabupaten Parigi Moutong. Kecamatan Parigi Tengah. Desa Binangga. Cagar Alam Pangi Binangga. 0 ${ }^{\circ} 47^{\prime} 14.2^{\prime}$ 'S, $120^{\circ} 4$ '43.5' 'E, RR023, 329 mdpl. R. Rizaldi, D. Moh. Fauzan, Zainudin, A. Muratno, Fedrik, dan Irwandi (13 Oktober 2019). Spesimen disimpan di Laboratorium
Biosistematika Tumbuhan. Jurusan Biologi FMIPA Univ. Tadulako.

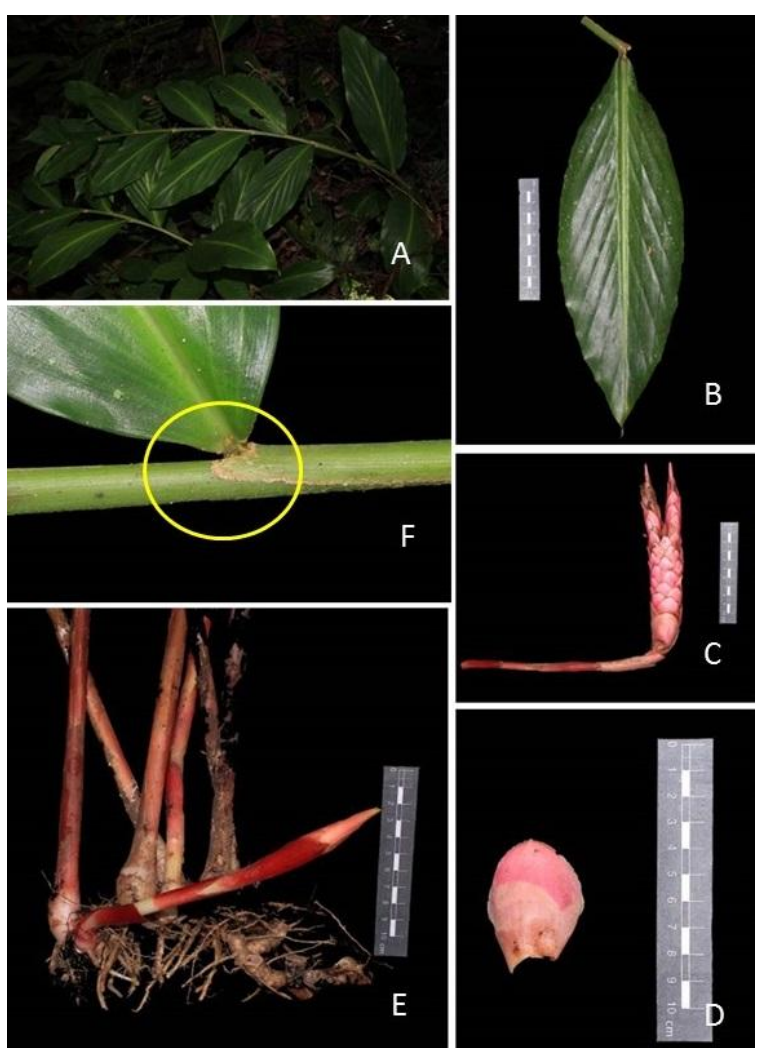

Gambar 9. Zingiber sp. A. Perawakan, B. Daun, C. Perbungaan, D. Bagian Bunga, E. Rimpang dan F. Ligula.

\section{KESIMPULAN}

Berdasarkan hasil penelitian yang telah dilakukan kesimpulan yang dapat di peroleh yaitu: terdapat 8 jenis yang terdiri atas 4 marga dari Zingiberaceae di lokasi penelitian yaitu; Alpinia eremoclamis, A. rubricaulis, Alpinia sp1, Alpinia sp2, Etlingera tubilabrum Etlingera $s p$, Sulettaria $s p$ dan Zingiber $s p$.

\section{UCAPAN TERIMA KASIH}

Penulis ingin menyampaikan ucapan terima kasih kepada D. Moh. Fauzan, Zainudin, A. Muratno, Fedrik dan Irwandi atas bantuannya selama kerja di lapangan. Kepada Kepala BKSDA Sulawesi Tengah yang telah memberikan izin kepada penulis untuk izin memasuki kawasan.

\section{DAFTAR PUSTAKA}

APG (2016) An Update of The Angiosperm Phylogeny Group Classification for The Orders and Families of Flowering Plants. Botanical Journal of the Linnean Society of London. 181(1): 1-20. 
Balai Konservasi Sumber Daya Alam Sulawesi Tengah [BKSDA Sulteng] (2015) Penataan Blok Cagar Alam Pangi Binangga Kabupaten Parigi Moutong Provinsi Sulawesi Tengah. Palu.

Bridson D, Forman L (1999) The Herbarium Handbook. Third edition. Royal Botanic Gardends. Kew, London.

Jiang, Delin WU, Karl L (2000) Flora of China: Zingiberaceae. Science Press. Beijing

Kress WJ and Specht CD (2005) Between Cancer and Capricorn: Phylogeny, evolution and ecology of the primarily tropical Zingiberales. Biol. Skr. 55: 459478.

Heyne K (1987) Useful Plants of Indonesia III. Center for Forest Research and Development. The Ministry of Forestry Republic of Indonesia. Bogor, Indonesia

Larsen K, Ibrahim H, Khaw SH, and Saw LG (1999) Gingers of Peninsular Malaysia and Singapore. Malaysia.

Mabberley DJ (2009) Mabberley's Plant Books. A Portable Dictionary of Plants, their classification and uses. Third Edition. Cambridge University Press. Cambridge, UK.

Newman M, Lhuillier A, Poulsen AD (2004) Checklist of the Zingiberaceae of Malesia. J Blum Suppl 16: 1-165

Pitopang R, Damry, Rusdi, Hamzah B, Zubair MS, Amar Al, Fathurahman, Basri Z, Poulsen DA. (2018) Diversity of Zingiberaceae and traditional uses by three indigenous groups at Lore Lindu National Park, Central Sulawesi, Indonesia. J. Phys.: Conf. Ser. 1242

Pitopang R, Umrah, Harso W, Nurainas dan Zubair MS (2020) Some botanical aspects and antifungal activity of Etlingera flexuosa (Zingiberaceae) from Central Sulawesi, Indonesia.Biodiversitas. 21 (8): 3547-3553

Poulsen DA (2013) Etlingera of Sulawesi. Natural History Publications. Borneo.

Poulsen DA, Mathisen BH, Newman FM, Ardiyani M, Lofthus O, Bjora SC (2018) Sulettaria: A new ginger genus disjunct from Elettaria cardamomum. Taxon 67 (4) : 725-738

Prabhukumar K M, Thomas V P, Sabu M, Prasanth A P and Mohanan K V (2015) Induced mutation in ornamental gingers (Zingiberaceae) using chemical mutagens viz. Colchicine, Acridine and Ethylmethanesulphonate J.of Hort.Forest and Biotech. 19 (2) 18-27

Ramadanil, Damry, Rusdi, B. Hamzah dan MS Zubair (2019) Traditional Usages and Phytochemical Screenings of Selected Zingiberaceae from Central Sulawesi, Indonesia. Pharmacogn J. 11(3): 505-510

Saleh MFRS dan Hartana (2018) Keanekaragaman Jenis Tumbuhan Jenis Tumbuhan Cagar Alam Pangi-Binangga, Sulawesi Tengah. Media Konservasi 22 (3): 286-292

Stearn WT (1992) Botanical Latin. Ed ke-4. Timber Press Portland. Oregon

Sukari MA, Sharif NWM, Yap ALC, Tang SW, Neoh BK, Rahmani M, Ee GCL, Taufiq-Yap YH dan Yuso UK (2008) Chemical Constituents Variations of Essential oils From Rhizomes of Four Zingiberaceae Species. The Malaysian Journal of Analytical Sciences, 12 (3): 638 644

Utteridge $T$ and Bramley $G$ (2015) The Kew Tropical Plant family identification handbook, second edition. Kew Publishing Royal Botanical Gardens. London

Van Balgooy MMJ (1997) Malesian Seed Plants. Volume 1. Rijksherbarium-Hortus Botanicus. Leiden

Van Balgooy MMJ (1998) Malesian Seed Plants. Volume 2. Rijksherbarium-Hortus Botanicus. Leiden

Van Balgooy MMJ (2001) Malesian Seed Plants. Volume 3. Rijksherbarium-Hortus Botanicus. Leiden

Zubair MS, Maulana S, Widodo A, Mukaddas A, Pitopang R (2020) Docking study on anti-HIV-1 activity of secondary metabolites from Zingiberaceae plants. J Pharm Bioall Sci.12 (6): 763-767. 